\title{
Multifunctional fuel cell system in an aircraft environment: An investigation focusing on fuel tank inerting and water generation
}

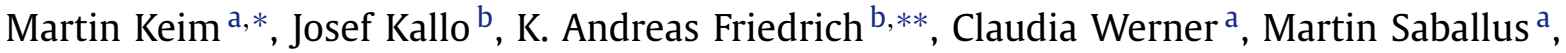 \\ Florian Gores ${ }^{a}$
}

a Deutsches Zentrum für Luft- und Raumfahrt (DLR), Institut für Technische Thermodynamik, Hein-Saß-Weg 38, 21129 Hamburg, Germany

${ }^{\mathrm{b}}$ Deutsches Zentrum für Luft- und Raumfahrt (DLR), Institut für Technische Thermodynamik, Pfaffenwaldring 38-40, 70569 Stuttgart, Germany

\section{A R T I C L E I N F O}

\section{Article history:}

Received 28 January 2013

Received in revised form 5 April 2013

Accepted 15 April 2013

Available online 19 April 2013

\section{Keywords:}

Fuel cell

Aviation

Inerting

Water generation

Hydrogen

PEMFC

\begin{abstract}
A B S T R A C T
Implementing a proton exchange membrane fuel cell (PEMFC) into an aircraft environment is a challenging task. In order for aircraft manufacturers and airlines to realize the ecological and economic benefits of this technology, it is necessary to make use of the multiple functions that a fuel cell system can provide. In addition to the main product of electrical energy, the fuel cell is capable of delivering further products, which are useful in an aircraft environment. The waste products - water vapor, heat and oxygen-depleted air (ODA) - at the cathode exhaust are valuable for use on board a commercial airplane. This paper describes the multifunctional approach, points out the advantages of the operation strategy as well as describes a prototype system for the multifunctional use of a PEM fuel cell on board a commercial airplane. The stable operation of the aforementioned system was successfully demonstrated in various tests. The emphasis of the work in question is on water and ODA generation/conditioning.
\end{abstract}

(C) 2013 Elsevier Masson SAS. All rights reserved.

\section{Introduction}

The implementation of a low temperature proton exchange membrane fuel cell (PEMFC) on board a commercial aircraft is a promising approach to decreasing emissions and to a more efficient aircraft. For the foreseeable future, fuel cell (FC) systems do not have the power density needed to replace the main engines, but could replace on-board power generators like the auxiliary power unit (APU). Following a general trend, aircraft manufacturers are trying to replace hydraulic systems with electrically driven systems. Modern aircraft, which are increasingly electrically operated, require more electrical power. Fuel cells can provide the additional electric power needed with superior electrical efficiency.

In order to implement this application within the challenging environment of an aircraft, it is necessary to improve the overall performance and use the multiple functions of the FC in order to justify the additional fuel $\left(\mathrm{H}_{2}\right)$ and weight compared to the conventional production of electric power on board. In addition to electrical energy, the fuel cell provides additional interesting products which are useful in an aircraft environment such as water and oxygen-depleted air (ODA). This paper will present a multifunctional prototype FC system for ODA and water generation.

\footnotetext{
* Corresponding author. Tel.: +49 40743 58455; fax: +49 4074374727 .

** Corresponding author.

E-mail addresses: martin.keim@dlr.de (M. Keim), andreas.friedrich@dlr.de (K.A. Friedrich).
}

A new multifunctional system architecture was planned, installed and tested in the test facilities of Airbus/German Aerospace Center (DLR) in Hamburg, Germany. The goal of the investigation was to showcase the operation of an FC as a device with multiple functions, which provides a demonstration of the overall usefulness of the FC in an aircraft environment. The main focus of the investigation was water and ODA generation/conditioning.

\section{State of the art}

Electrical consumption on board of an aircraft is supplied by the APU during ground operation or by the main engines during flight. The electrical efficiency of generation from the main engines is 30$40 \%$ in the best case [13]. Ground operation of the APU is in most cases below 20\% [13]. Furthermore, noise and exhaust emissions (mainly $\mathrm{CO}_{2}$ and $\mathrm{NO}_{X}$ ) are emitted $[10,13]$.

The current safety approach to prevent combustion within jet fuel tanks is to eliminate as many ignition sources as possible. Since many electrical devices like fuel pumps, level sensors or valves are mandatory to ensure the aircrafts operation, it is not possible to eliminate all risks [3]. Additional external environmental effects, such as lightning, cannot be prevented. If the vapor space created above the fuel is flammable, the level of safety is limited, as Fig. 1 shows.

Currently, the water supply on board commercial airplanes is ensured through the use of water tanks which need to be filled prior to take off and which increase the jetliners take-off weight. 


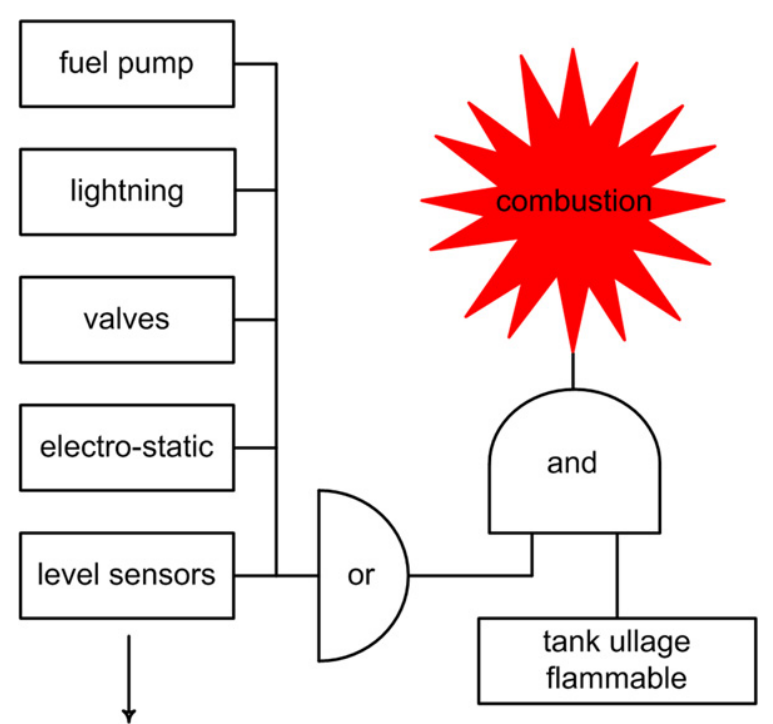

etc.

Fig. 1. Hazards of fuel air mixture combustion.

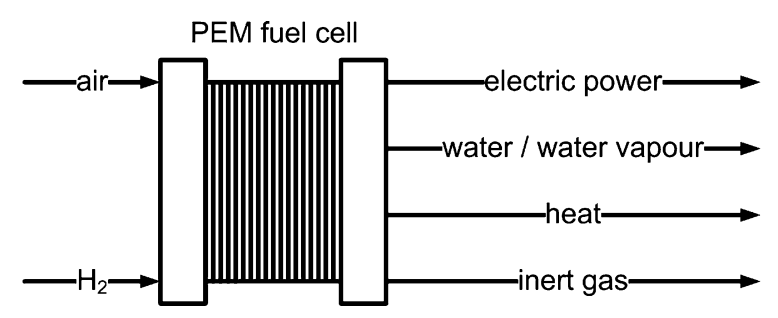

Fig. 2. Educts and products of PEM fuel cell systems.

Airlines are dependent on the water quality the airports supply and do not have the ability to control water quality themselves. In some cases water quality provided by the airports is unsatisfactory and may be contaminated with bacteria, which can endanger passenger health [15]. In order to protect customer health, airlines carry enough water to last for the return flight to the home airport without loading water at the destination. In some cases this can be over $1700 \mathrm{~L}$ for a long range Boeing aircraft [15].

\section{The multifunctional concept}

Electric power is not the only item, which is produced while operating a PEMFC. There are three additional products which are generated and can be used in an aircraft environment (see Fig. 2).

The electrical power generation by a PEM FC system including all peripheral loads can reach electrical efficiencies of up to $50 \%$ [14], which is certainly more efficient than the production with an APU or the main engines. Furthermore, the FC only emits ODA and water vapor but no $\mathrm{CO}_{2}, \mathrm{NO}_{X}$ or other environmentally harmful gases [8]. By replacing on-board power generators like the APU with a fuel cell, noise emissions during ground operation are minimized, in addition there are advantages such as improved electrical efficiency and lowered emissions.

The emitted water and water vapor can, if condensed, be used in lavatories, galleys and for humidification. Since the produced water is demineralized, it is especially adequate for humidification purposes. If high quality materials are used which conform to the requirements of the Food and Drug Association (FDA), the water that is produced is relatively clean. Only a minimum level of pretreatment, such as $\mathrm{pH}$ adjustment, is needed to meet Environmental Protection Agency (EPA) standards for drinking water [4].
Table 1

Overview of electrical consumers on board a Boeing 787.

\begin{tabular}{ll}
\hline Pressurization & $250 \mathrm{~kW}$ \\
Galley forward & $40 \mathrm{~kW}$ \\
Galley aft & $60 \mathrm{~kW}$ \\
Entertainment system & $20 \mathrm{~kW}$ \\
Sum & $390 \mathrm{~kW}$ \\
\hline
\end{tabular}

The new Boeing 787 (B787) is an example of a More Electrical Aircraft (MEA) where more and more functions on board are electrically supported. As opposed to all other Boeing models the air pressure at high altitudes inside the B787 cabin is not supplied by bleed air from the engines. Instead a compressor pressurizes ram air to provide the fresh air demand for passengers [11]. More than $25 \%$ of the $1 \mathrm{MW}$ the engine generators can supply are used during flight for cabin pressurization [11] which equals $250 \mathrm{~kW}$. Table 1 shows four more major electric consumption points on board a B787.

Using a flight from John F. Kennedy Airport (JFK) to San Francisco Airport (SFO) which takes about $5 \mathrm{~h}$ for a distance of $4139 \mathrm{~km} \mathrm{[11]} \mathrm{as} \mathrm{an} \mathrm{example,} \mathrm{the} \mathrm{needed} \mathrm{electrical} \mathrm{energy} \mathrm{to} \mathrm{sup-}$ ply the consumption points shown in Table 1 can be calculated as follows.

$Q_{\text {dot }}=390 \mathrm{~kW} * 5 \mathrm{~h}=1950 \mathrm{kWh}$

A PEM fuel cell delivers about $0.5 \mathrm{~L}$ of water per $\mathrm{kWh}$ of generated electrical power, depending on the condensation temperature [14]. Therefore it is theoretically possible to produce $975 \mathrm{~L}$ of drinking water on a flight from JFK to SFO. A B787 can carry up to $1022 \mathrm{~L}$ of fresh water [11]. It has been demonstrated that the amount of water produced by the PEM is sufficient considering that the range of a $B 787$ is $15,200 \mathrm{~km} \mathrm{[1]} \mathrm{where} \mathrm{even} \mathrm{more}$ water could be produced than the $B 787$ water tanks are able to carry. It would not be necessary to fill the water tank prior to take off, if the FC water is used. Using this method, the starting weight of a commercial aircraft could be reduced significantly.

Furthermore, the airlines could control the water quality they provide on board, eliminating their dependency on the quality of the water supplied by the airport operator as described in Section 2.

New regulations set by the Federal Aviation Administration (FAA) and European Aviation Safety Agency (EASA) force aircraft manufacturers as well as aircraft operators to introduce further measures to reduce flammability within the fuel tanks, such as inerting the vapor space inside the fuel tanks $[5,6]$. In order to meet the FAA and EASA standards it is necessary to prevent the development of flammable gas mixtures within the tank during operation of the main engines. Therefore the ODA provided by the fuel cell could be used as inert gas to fill the ullage which is created while drawing fuel from the tank during aircraft operation. This eliminates the problem of critical fuel air mixtures within the tank. The balanced approach (see Fig. 1) of inerting the ullage results in a higher level of safety by avoiding possible ignition due to lack of oxygen [3].

The emitted heat from the electrochemical process within the FC can be used for wing anti-icing or warm water production $[2,14]$.

\subsection{Inert gas generation}

By reducing the fuel cells air stoichiometry $(\lambda)$ it is possible to attain oxygen concentrations of $10 \mathrm{vol} \%$ at the cathode exhaust [14]. The produced ODA can be injected into the fuel tanks filling the vapor space. The low oxygen content created within the ullage 


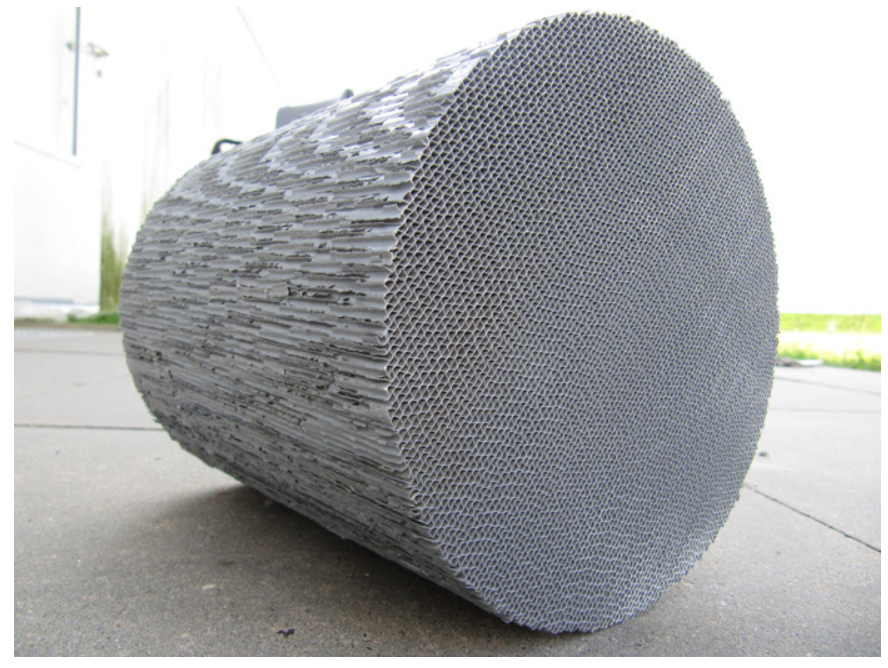

Fig. 3. Honeycomb silica structure by Proflute.

by injecting ODA guaranties a nonflammable noncombustible environment even if there is an ignition source. However, before the ODA can be used as inert gas, the gas must be dried. With a temperature of approximately $50^{\circ} \mathrm{C}$ and a relative humidity of $100 \%$ the fuel cell exhaust in the form of ODA would introduce large amounts of water into the fuel tanks. Especially at high altitudes and low temperatures, condensing water vapor would contaminate the fuel and freeze within the tank [2]. In order to prevent contamination of jet fuel and consequential ice formation it is necessary to dry the ODA to a specific humidity not above $2 \mathrm{~g}\left(\mathrm{H}_{2} \mathrm{O}\right) \mathrm{kg}^{-1}$ ODA (henceforth referred to as $\mathrm{g} \mathrm{kg}^{-1}$ ) as a time-averaged mean value [2].

\subsection{Honeycomb silica structure}

In order to fulfill the drying requirements, it is not sufficient to dry the ODA solely through condensation. For decades, hygroscopic silica honeycomb structures have been used for energy recovery systems as well as in air desiccating and humidification [16]. The structures consist of $82 \%$ silica gel $\left(\mathrm{SiO}_{2}\right)$ strengthened with $16 \%$ glass fiber. The remaining $2 \%$ is an acrylic surface coating [12]. The drying mechanism within the silica structure is physisorption [17]. Chemisorption does not take place while steam is adsorbed. To regenerate the hygroscopic behavior after drying the material needs to be heated up to a temperature of $100-200^{\circ} \mathrm{C}$ [7]. The honeycomb silica structures used in this project were $160 \mathrm{~mm}$ in diameter and $200 \mathrm{~mm}$ in length (see Fig. 3).

The material is not flammable. After ASTME Test E.84 [12] the material has a flame and smoke index of 0 [12]. Especially for airborne use, a low flammability is absolutely necessary.

\subsection{The system}

The architecture of the prototype including a post-drying system for ODA is shown in Fig. 5. The conventional design shown in Fig. 4 has no extra drying stage after condensation and separation. This system solely delivers water and ODA with a minimum dew point $>0{ }^{\circ} \mathrm{C}$. It is not possible to meet the required specific humidity of $<2 \mathrm{~g} \mathrm{~kg}^{-1}$ as described in Section 3.1. The conventional design has also been tested at the Airbus/DLR test facilities in Hamburg, Germany.

The fuel cell system used was a HyPM XR12 rack mounted FC system manufactured by Hydrogenics in Canada. For performance data see Table 2.

Each unit in Fig. 5 is a cartridge with a honeycomb silica structure inside (see Fig. 3). The concept behind the design is a dry-

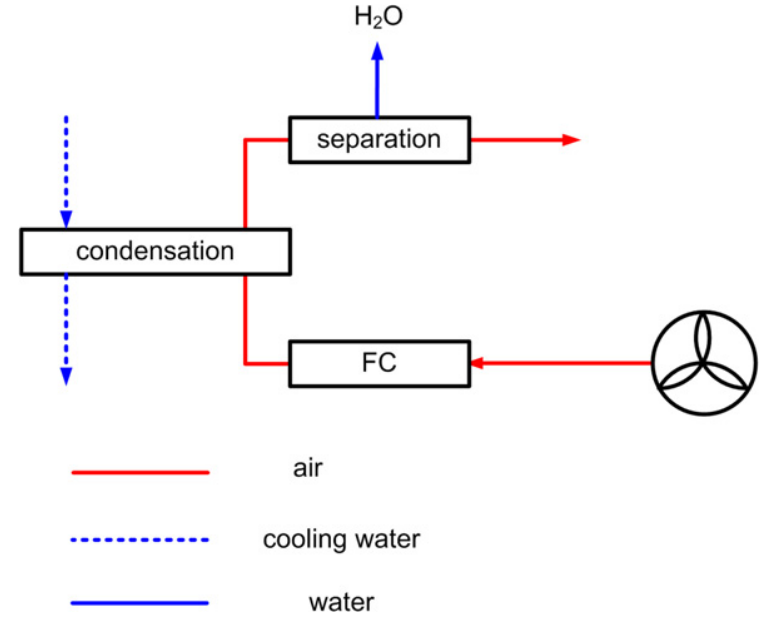

Fig. 4. System architecture of a conventional design.

Table 2

Performance data FC system HyPM XR12.

\begin{tabular}{ll}
\hline Maximum power & $12.5 \mathrm{kWh}$ \\
Voltage range & $30-60 \mathrm{VDC}$ \\
Maximum operating current & $350 \mathrm{~A}$ \\
Mass & $80 \mathrm{~kg}$ \\
Peak net efficiency & $53 \%$ \\
\hline
\end{tabular}

ing/regeneration process which takes place in cycles. Each unit cycles through 3 phases (drying, regeneration, resting). In order to maintain a continuously running process within the FC, three units are necessary to ensure that, even during phase changes, the airflow is never interrupted.

The airflow needed to feed the electrochemical process of the FC is delivered by a blower. Before entering the FC the airflow is used to regenerate the drying units. Therefore the air is heated and introduced into a unit which has been drying in the previous cycle (as an example consider that the valves V7 and V8 are open and consequently unit 2 is being regenerated). After the moist airstream exits the unit it is introduced to the FC to feed the electrochemical process. At the exhaust of the FC (green lines in Fig. 5) the ODA is run through a condenser where it is cooled. An air/water separation is required to protect the silica gel structures from liquid water. The pre-dried stream of ODA enters one of the units for further drying (example: V1 and V2 open $\rightarrow$ unit 1 is drying). During this post-drying process the needed humidity is achieved. While unit 1 and unit 2 are in operation unit 3 is in rest mode in order to cool down from the previous regeneration cycle to increase performance in the upcoming drying cycle.

This described approach has an additional advantage. Since a pressure gradient within the system does not affect operation it would be possible to use the pressure difference in a jetliner from cabin to atmosphere at cruising altitude. At an altitude of about $10 \mathrm{~km}$ the absolute atmospheric pressure is about $200 \mathrm{mbar}$ while the absolute cabin pressure of a jetliner is about 700 mbar. If this gradient would be utilized the airstream necessary to feed the system could be sucked through the system making an active blower unnecessary. This would increase the FCs efficiency by eliminating a peripheral load. The pressure and air change inside the cabin must be available even without an FC system since it is mandatory for the passenger's survival during flight. Therefore, no additional energy is needed if the FC is fed by cabin pressure.

\section{Laboratory tests}

The described system was set up at the DLR/Airbus laboratories in Hamburg, Germany (see Fig. 6). Intensive testing demonstrated 


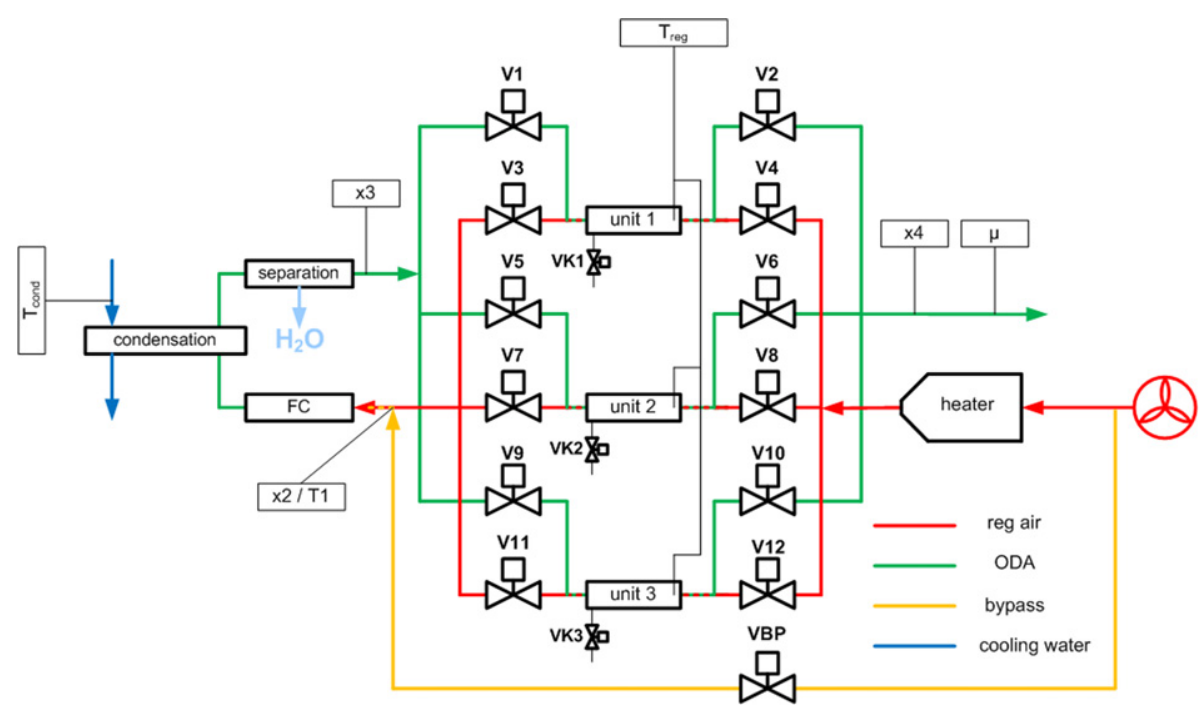

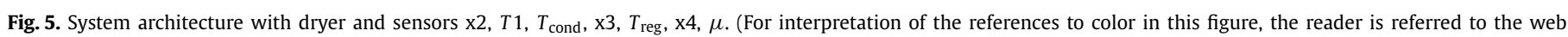
version of this article.)

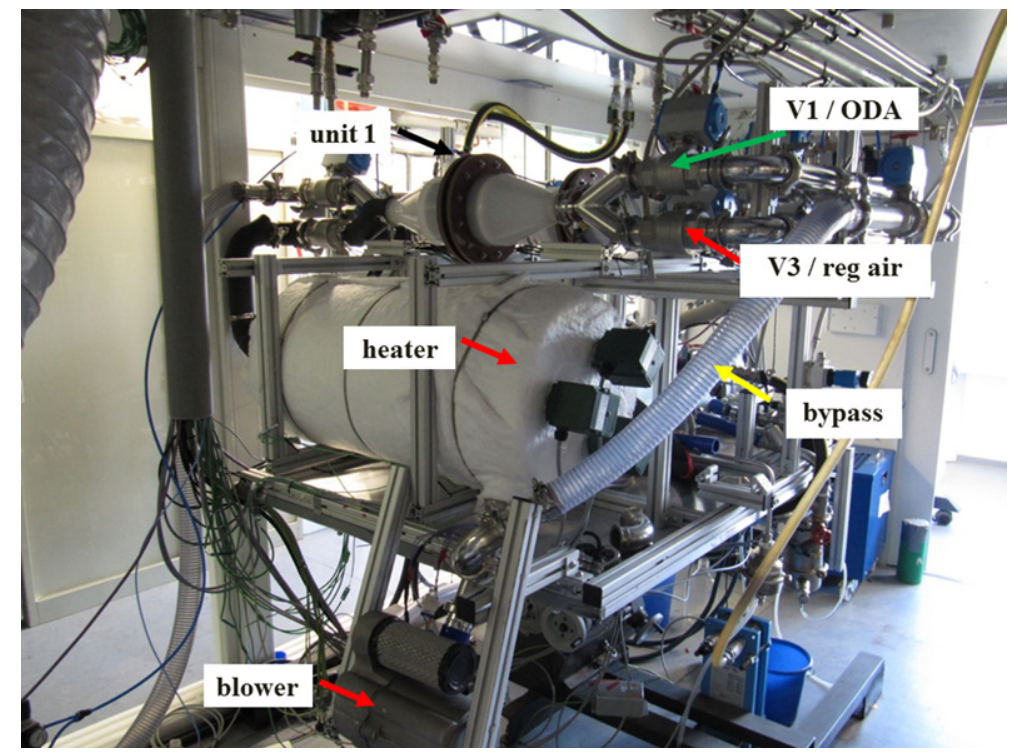

Fig. 6. Laboratory test rig.

the functionality of the developed system architecture. The numeric value which demonstrates the quality of the drying process is the level of specific humidity at the system's exhaust (see Fig. 5, value at position $\mathrm{x} 4$ ). The water output is measured at the outlet of the separation. In order to compare the results more easily the specific water output in $\mathrm{kg}\left(\mathrm{H}_{2} \mathrm{O}\right) \mathrm{kWh}^{-1}$ (henceforth referred to as $\mathrm{kg} \mathrm{kWh}^{-1}$ ) is calculated. The mass of the water produced is divided by the electric energy provided by the FC.

The characteristic curve shape showing several peaks in specific humidity (at position $\mathrm{x} 4$ ) in Figs. 7 to 9 is caused by the batch operation of the drying system. Before a drying unit begins the drying cycle it is regenerated in the cycle before. Coming out of the regeneration cycle the silica material as well as the cartridge is still hot. When the silica material is too hot the drying process cannot take place properly which results in moist ODA passing through the drying stage. The gradient of vapor pressure of the material and the ODA is not large enough for adsorption to take place when the material is still hot. When the incoming ODA cools the materials, the drying process begins. The vapor pressure of the silica decreases with the decreasing temperature of the material [17]. $\mathrm{x} 4$ drops below the critical value of $2 \mathrm{~g} \mathrm{~kg}^{-1}$. These peaks do not endanger the overall drying result since the mean value of $\mathrm{x} 4$ remains below the set benchmark in all but one test run.

The following three test runs have been performed. The parameter's positions which have been varied can be found in Fig. 5.

1. Variation of regeneration temperature $\left(T_{\text {reg }}\right)$;

2. Variation of condenser temperature $\left(T_{\text {cond }}\right)$;

3. Variation of ODA flow $(\mu)$.

All test runs are limited to $7200 \mathrm{~s}$.

\subsection{Variation of regeneration temperature}

In this test run mean $T_{\text {cond }}=10.2{ }^{\circ} \mathrm{C}$ and $\mu=5 \mathrm{~g} \mathrm{~s}^{-1}$ are held constant while varying $T_{\text {reg. }}$.

Fig. 7 shows the specific humidity vs. time at the system exhaust ( $\mathrm{x} 4)$ at varying regeneration temperatures ( $T_{\text {reg }}$ in Fig. 5 ). The value $T_{\text {reg }}$ always refers to the inlet temperature of the unit 
time vs. specific humidity at system exhaust with variable regeneration temperature

$$
\mathrm{FC} \text { power }=6 \mathrm{~kW} / \mathrm{T}_{\text {cond }}=10.2^{\circ} \mathrm{C} / \mu=5.0 \mathrm{~g} \mathrm{~s}^{-1}
$$

$$
\begin{aligned}
\text { mean } \mathrm{T}_{\text {reg }} & =94^{\circ} \mathrm{C} \\
\text { mean } \mathrm{T}_{\text {reg }} & =102^{\circ} \mathrm{C} \\
\text { mean } \mathrm{T}_{\text {reg }} & =107^{\circ} \mathrm{C}
\end{aligned}
$$
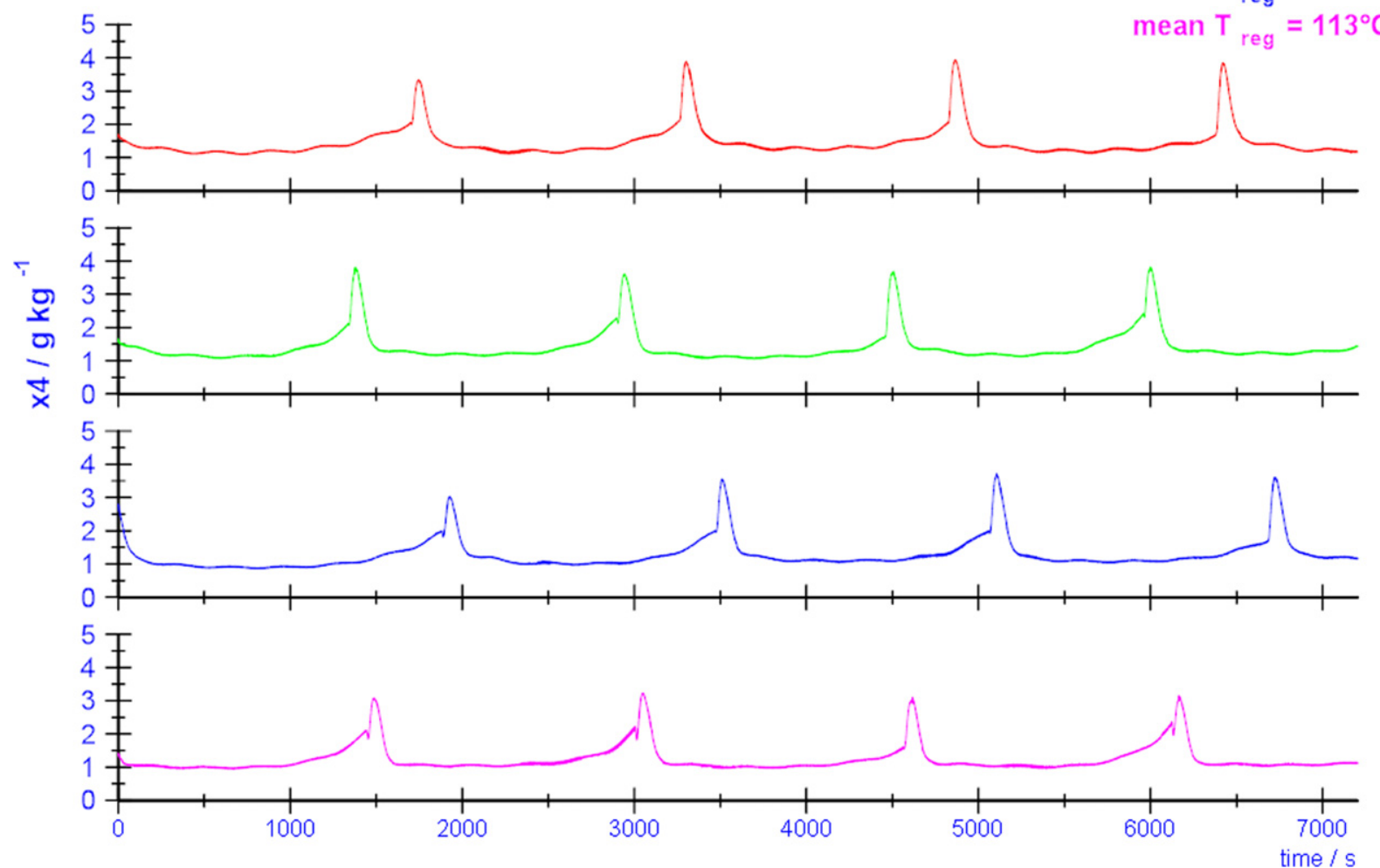

Fig. 7. Time vs. humidity at system exhaust at variable regeneration temperature.

Table 3

Specific humidity at varying regeneration temperatures.

\begin{tabular}{cll}
\hline $\begin{array}{l}\text { Mean regeneration } \\
\text { temperature } T_{\text {reg }}\left[{ }^{\circ} \mathrm{C}\right]\end{array}$ & $\begin{array}{l}\text { Mean spec. hum. } \\
\text { at x4 }\left[\mathrm{g} \mathrm{kg}^{-1}\right]\end{array}$ & Drying criterion met? \\
\hline 94 & 1.5 & yes \\
102 & 1.4 & yes \\
107 & 1.3 & yes \\
113 & 1.3 & yes \\
\hline
\end{tabular}

which is operating in the regeneration cycle. The cycle times are not affected and remain at $\sim 1500 \mathrm{~s}$ at all operation points.

As shown in Table 3 the criterion of mean $x 4$ humidity value being below $2 \mathrm{~g} \mathrm{~kg}^{-1}$ was met in all test runs. The specific humidity at $\mathrm{x} 4$ is decreasing with increasing temperatures $\left(T_{\mathrm{reg}}\right)$. Due to the higher regeneration temperatures deeper regions in the silica structures are regenerated and dried [9] resulting in better drying performance. But since even at $T_{\mathrm{reg}}=94^{\circ} \mathrm{C}$ with $\mathrm{x} 4=1.5 \mathrm{~g} \mathrm{~kg}^{-1}$ the criterion was easily met, the lower set points should be preferred in order to conserve energy in the heating process.

\subsection{Variation of condensation temperature}

In this test run, mean $T_{\text {reg }}=107^{\circ} \mathrm{C}$ and $\mu=5 \mathrm{~g} \mathrm{~s}^{-1}$ were held constant while varying $T_{\text {cond }}$.

When the condensation temperature (see $T_{\text {reg }}$ in Fig. 5 ) at the condenser is increased, the specific humidity (x3) at the dryer inlet rises (see Table 4). The water burden introduced into the drying units is increasing with increasing temperature $T_{\text {cond }}$ resulting in
Table 4

Specific humidity at varying condenser temperatures.

\begin{tabular}{llll}
\hline $\begin{array}{l}\text { Mean condenser } \\
\text { temperature } T_{\text {cond }}\left[{ }^{\circ} \mathrm{C}\right]\end{array}$ & $\begin{array}{l}\text { Mean spec. } \\
\text { hum. x3 }\left[\mathrm{g} \mathrm{kg}^{-1}\right]\end{array}$ & $\begin{array}{l}\text { Mean spec. } \\
\text { hum. } \mathrm{x} 4\left[\mathrm{~g} \mathrm{~kg}^{-1}\right]\end{array}$ & $\begin{array}{l}\text { Drying cri- } \\
\text { terion met? }\end{array}$ \\
\hline 6.6 & 7.3 & 1.3 & yes \\
10.2 & 9.4 & 1.6 & yes \\
14.9 & 12.1 & 1.8 & yes \\
19.8 & 17.0 & 3.0 & no \\
\hline
\end{tabular}

a failure of the system at $T_{\text {cond }}=19.9^{\circ} \mathrm{C}$. The difference between incoming specific humidity $\mathrm{x} 3=17 \mathrm{~g} \mathrm{~kg}^{-1}$ and the goal of $\mathrm{x} 4<$ $2 \mathrm{~g} \mathrm{~kg}^{-1}$ is too great.

The time each unit is able to dry decreases with rising condenser temperature $T_{\text {cond }}$ (see Fig. 8). The cycle time drops from $\sim 1700 \mathrm{~s}$ at $T_{\text {cond }}=6.6^{\circ} \mathrm{C}$ to $\sim 1400 \mathrm{~s}$ at $T_{\text {cond }}=10.2^{\circ} \mathrm{C}$. At $T_{\text {cond }}=14.9^{\circ} \mathrm{C}$ the cycle time is reduced further to $\sim 1000 \mathrm{~s}$ and reaches $0 \mathrm{~s}$ at $T_{\text {cond }}=19.8^{\circ} \mathrm{C}$. Even though the graph in Fig. 8 shows a cycle behavior the cycle time is $0 \mathrm{~s}$ since $\mathrm{x} 4$ never reaches the goal of $\mathrm{x} 4<2 \mathrm{~g} \mathrm{~kg}^{-1}$.

While the goal of a maximum water load of $2 \mathrm{~g} \mathrm{~kg}^{-1}$ is met with condenser temperatures of $6.6^{\circ} \mathrm{C}, 10.2^{\circ} \mathrm{C}$ and $14.9{ }^{\circ} \mathrm{C}$ the system fails at a temperature of $19.8^{\circ} \mathrm{C}$ (see Table 4). The dimensions of the silica structures are too small to adsorb the increasing water burden of the incoming ODA. In order to conserve energy, higher condenser temperatures are preferable since less cooling demand reduces peripheral energy consumption. Since the system still shows satisfactory drying results at $T_{\text {cond }}=14.9{ }^{\circ} \mathrm{C}$ it is acceptable to operate at this temperature. 


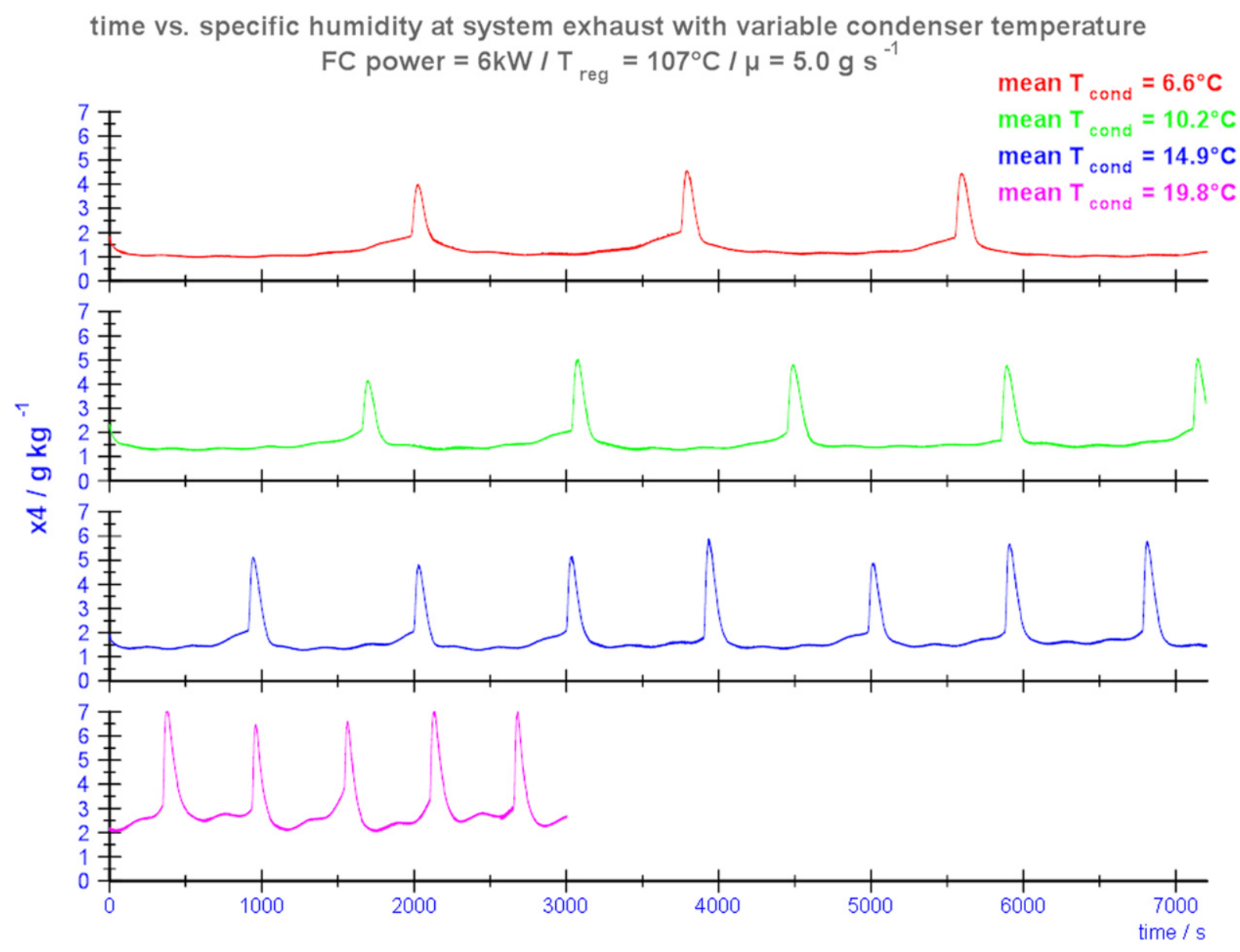

Fig. 8. Time vs. humidity at system exhaust at variable condenser temperature.

Table 5

Specific humidity at varying FC power/mass flow of ODA $(\mu)$.

\begin{tabular}{llll}
\hline $\begin{array}{l}\text { Mean FC } \\
\text { power }[\mathrm{kW}]\end{array}$ & $\begin{array}{l}\text { Mean ODA mass } \\
\text { flow } \mu\left[\mathrm{g} \mathrm{s}^{-1}\right]\end{array}$ & $\begin{array}{l}\text { Mean spec. hum. } \\
\mathrm{x} 4\left[\mathrm{~g} \mathrm{~kg}^{-1}\right]\end{array}$ & Drying criterion met? \\
\hline 4.3 & 3.3 & 1.0 & yes \\
6.0 & 5.0 & 1.1 & yes \\
7.6 & 6.7 & 1.1 & yes \\
\hline
\end{tabular}

\subsection{Variation of ODA flow}

In this test run mean $T_{\text {cond }}=10.2^{\circ} \mathrm{C}$ and mean $T_{\text {reg }}=107^{\circ} \mathrm{C}$ are held constant while varying $\mu$. When the power of the fuel cell is increased the mass flow of ODA ( $\mu$ in Fig. 5 ) is increased (see Table 5 ). The impact on the drying result is rather small as $\mathrm{x} 4$ shows in Table 5. The earlier tests with changing condenser temperature increased the water burden by raising the specific humidity (x3) at the dryer inlet. In this case the water load is increased by an increasing mass flow of ODA $(\mu)$. The system does not show a significant change in the drying result as shown in Table 5. Analogous to the test runs in Section 4.2 the specific humidity (x3) at the dryer inlet is at $\sim 9.4 \mathrm{~g} \mathrm{~kg}^{-1}$. But even with increasing $\mu$ the drying material is capable of reaching the benchmark easily, as shown in Table 5.

Only the cycle time of the system decreases with rising FC power, respectively ODA mass flow is shown in Fig. 9. Influenced by the increasing amount of water vapor that needs to be adsorbed when increasing $\mu$, the cycle time is reduced from $\sim 2900 \mathrm{~s}$ at $\mu=3.3 \mathrm{~g} \mathrm{~s}^{-1}$ to $\sim 1800 \mathrm{~s}$ at $\mu=5.0 \mathrm{~g} \mathrm{~s}^{-1}$. At $\mu=6.7 \mathrm{~g} \mathrm{~s}^{-1}$ the cycle time is $\sim 1300 \mathrm{~s}$.
The limitation of the system was not reached. Further testing is needed to answer the question about the field of work the system can cover.

\subsection{Water output}

The specific water output increases when using the described system architecture (see Fig. 5) compared to the conventional design (see Fig. 4). This is possible because the water absorbed by the drying units is reintroduced into the FC cathode inlet while regenerating the silica structures (see Fig. 5). During the regeneration cycle the specific humidity at the FC inlet rises to about $30 \mathrm{~g} \mathrm{~kg}^{-1}$ (see $\mathrm{x} 2$ in Fig. 5 and Fig. 11) because of the water which is desorbed from the drying material. The increased water load at the FC cathode inlet leads to an increase of the water output at condensation/separation. The specific water output increases from $0.498 \mathrm{~kg} \mathrm{kWh}^{-1}$ in the conventional design to $0.517 \mathrm{~kg} \mathrm{kWh}^{-1}$ in the new design including the dryer. In both cases $T_{\text {cond }}$ is at $10^{\circ} \mathrm{C}$.

Furthermore the condenser temperature ( $\left.T_{\text {cond }}\right)$ barely influences the water output. As shown in Fig. 10 the specific water output varies in a range of max. $0.007 \mathrm{~kg} \mathrm{kWh}^{-1}$ which is a deviation of $1.4 \%$. By increasing the condenser temperature the overall system efficiency rises because the energy demand for cooling is less. Nevertheless the system reaches the same water yield.

The high humidity at the FC inlet caused by the regeneration process does not show measurable changes in FC performance. The specific humidity at the FC cathode inlet reaches a maximum of $30 \mathrm{~g} \mathrm{~kg}^{-1}$ (see x2 in Fig. 11). Throughout all experiments the FC inlet temperature $T 1$ never exceeded $55^{\circ} \mathrm{C}$. 
time vs. specific humidity at system exhaust with variable FC power

$$
\mathrm{FC} \text { power }=6 \mathrm{~kW} / \mathrm{T}_{\text {cond }}=10.2^{\circ} \mathrm{C} / \mathrm{T}_{\text {reg }}=107^{\circ} \mathrm{C}
$$

$$
\mu=3.3 \mathrm{~g} \mathrm{~s}^{-1}
$$$$
\mu=5.0 \mathrm{~g} \mathrm{~s}^{-1}
$$
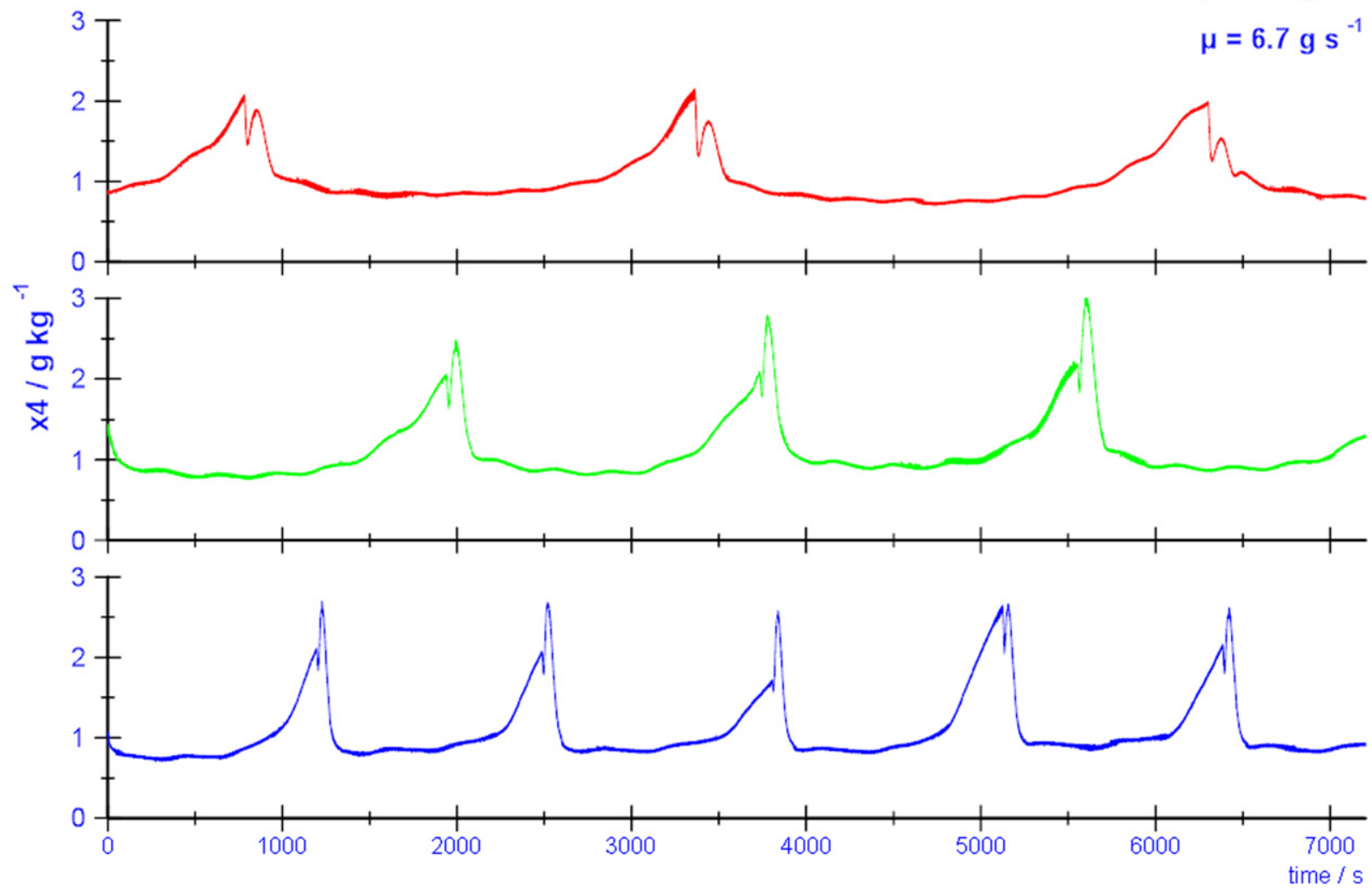

Fig. 9. Time vs. humidity at system exhaust at variable FC power.

comparison of specific water output using process designs with dryer at different condenser temperatures $\left(T_{\text {cond }}\right)$

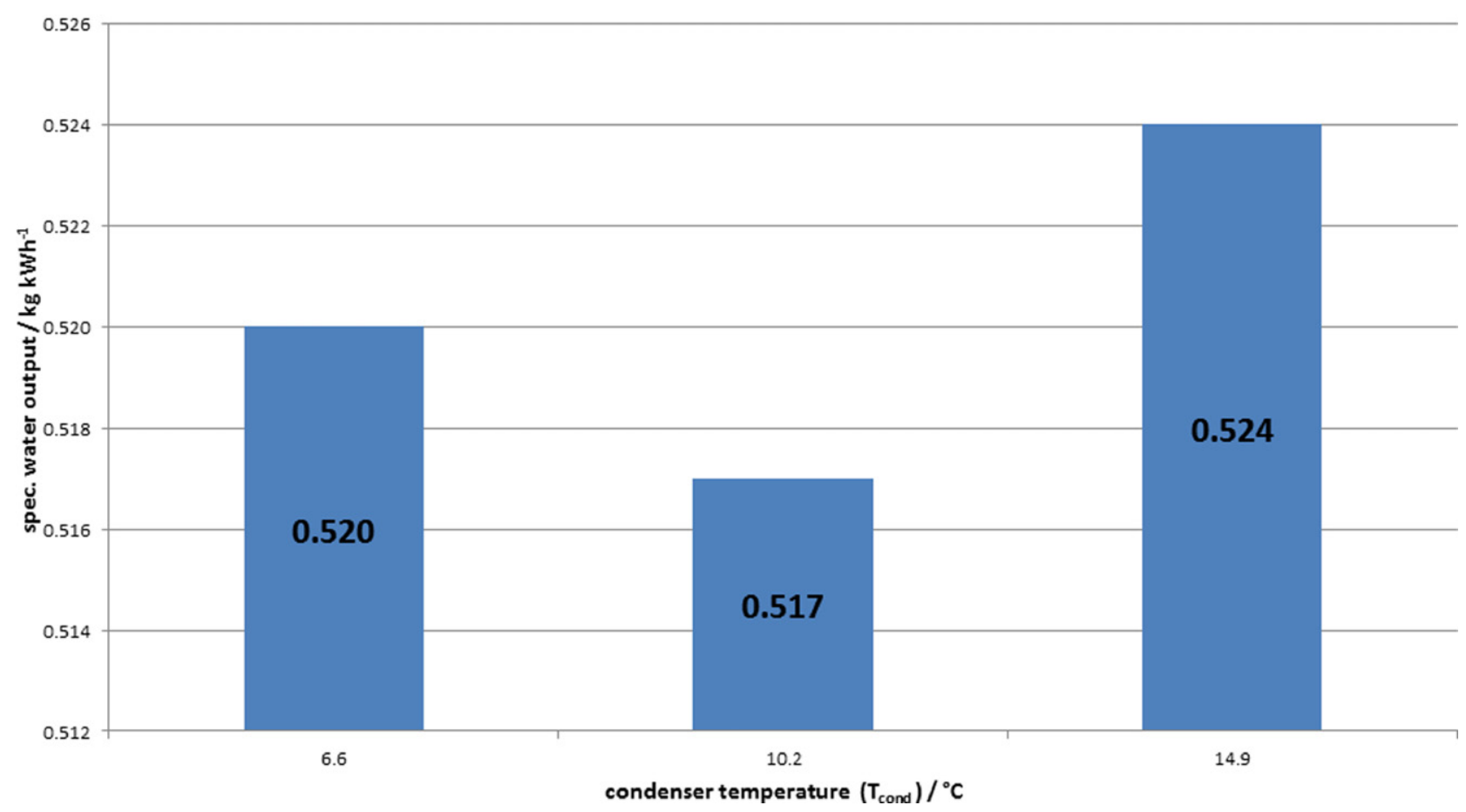

Fig. 10. Comparison of specific water output using different condenser temperatures. 


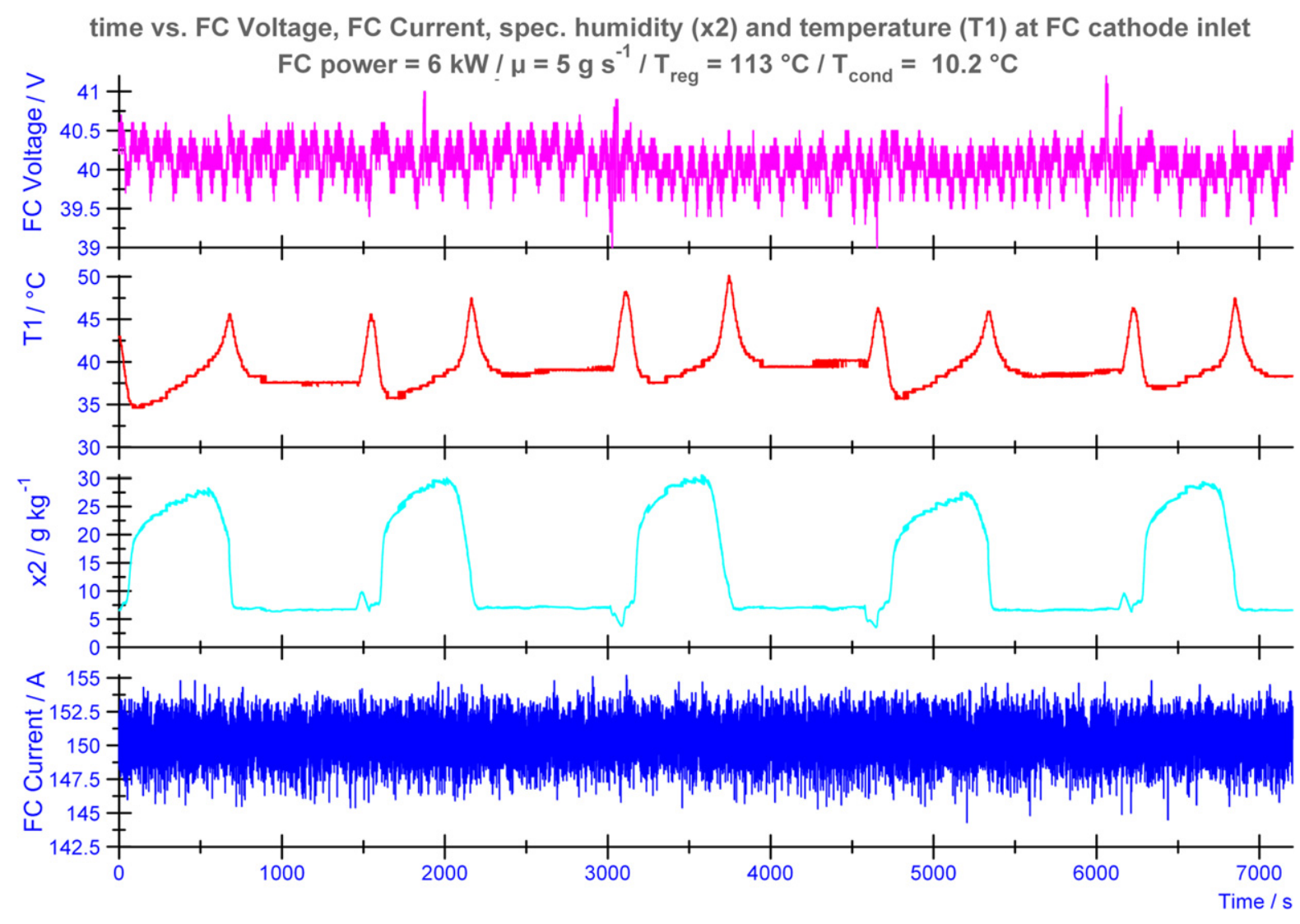

Fig. 11. Impact of varying specific humidities and temperature at FC cathode inlet.

\section{Conclusions}

The conditioning of FC cathode exhaust gas to reduce the flammability level within a jet fuel tank was successful. It is possible to reach specific humidity levels well below $2 \mathrm{~g}\left(\mathrm{H}_{2} \mathrm{O}\right) \mathrm{kg}^{-1}$ ODA using the architecture presented herein.

The water output was increased by $3.8 \%$ by the reintroduction of steam to the FC cathode inlet during the regeneration process. The FC performance was not affected by the additional peripheral components and changing environmental conditions.

The ideal set points $T_{\text {reg }}=94^{\circ} \mathrm{C}$ and $T_{\text {cond }}=14.9{ }^{\circ} \mathrm{C}$ for the most efficient operation of the system have been found.

It was shown, that by utilizing the multifunctional possibilities of an FC, the system in question demonstrates a promising approach for the implementation of a PEM FC system in an aircraft environment.

\section{Outlook}

Further test investigations of system behavior at lower pressure should be performed. The cabin pressure of a commercial airplane drops to $\sim 700 \mathrm{mbar}$ at cruising altitude. Furthermore, suction tests should be performed. If the pressure difference of $\sim 500$ mbar between the cabin and the atmosphere at cruising altitude can be used to suck the required air through the system, an additional peripheral consumer (blower) could be eliminated.

Since the results showed that even at low regeneration temperatures the systems reached the benchmark of $2 \mathrm{~g} \mathrm{~kg}^{-1}$, further tests within lower regeneration temperature ranges should be performed. Additional calculations may show that resizing the silica structures could decrease energy consumption if the system would deliver acceptable drying results at higher condenser temperatures.

However, another test series around increasing mass flows of ODA within the system should be performed because the system's limit could not be reached.
Long term testing related to real flight mission should be conducted in order to proof the system stability in real operating cycles.

Investigation concerning material, weight and packaging are inevitable since these are limiting factors in an aircraft environment.

\section{Abbreviations}

APU Auxiliary power unit

B787 Boeing 787

DLR Deutsches Zentrum für Luft- und Raumfahrt (German Aerospace Center)

EASA European Aviation Safety Agency

EPA Environmental Protection Agency

FAA Federal Aviation Administration

FC Fuel cell

FDA Food and Drug Association

JFK John F. Kennedy Airport

MEA More electrical aircraft

ODA Oxygen-depleted air

SFO San Francisco Airport

T1 Temperature $\left[{ }^{\circ} \mathrm{C}\right]$

$T_{\text {cond }} \quad$ Condenser temperature $\left[{ }^{\circ} \mathrm{C}\right]$

$T_{\text {reg }} \quad$ Regeneration temperature $\left[{ }^{\circ} \mathrm{C}\right]$

PEM Proton exchange membrane

PEMFC Proton exchange membrane fuel cell

spec. hum. Specific humidity

$\mathrm{x} 2-\mathrm{x} 4 \quad$ Specific humidity at different system locations $\left[\mathrm{g} \mathrm{kg}^{-1}\right]$

$\mu \quad$ Mass flow of oxygen-depleted air $\left[\mathrm{g} \mathrm{s}^{-1}\right]$

$\lambda \quad$ Cathode stoichiometry [-] 


\section{Acknowledgements}

The presented results are based on a team effort. The authors are grateful to the "EFFESYS" and "BRIST" teams, as well as to the Fuel Cell team of Airbus for the excellent collaboration during the past years. Financial support from the German Federal Ministry of Economics and Technology through project "EFFESYS", contract 20Y0803B and the German Federal Ministry Transport, Building and Urban Development through project "BRIST", contract 03BV113F, was essential for enabling the work, and is gratefully acknowledged.

The work of the unknown reviewers is appreciated.

Thank you for the spell check Thomas E. Buckley.

\section{References}

[1] Boeing, Boeing company website [online]. http://www.boeing.com/boeing/ commercial/787family/787-8prod.page, download 3/22/2013.

[2] Bundesministerium für Bildung und Forschung, Multifunktionale Brennstoffzelle Technical Showcase des Luftfahrtclusters Metropolregion Hamburg [online]. http://www.hightech-strategie.de/_media/HTS_SCW_TS_Luftfahrtcluster_ 110805.pdf, download 8/21/2012.

[3] D.I. Chenney, Fuel tank safety enhancements of large transport airplanes, in: The 57th Annual International Air Safety Seminar, Shanghai, China, Federal Aviation Administration, 2004

[4] B. Dhanasekaran, A new water source: Can fuel cells provide safe potable water sources? A thesis presented in partial fulfillment of the requirements for the Degree Master of Science, Arizona State University, Arizona, 2007, Graduate Supervisory Committee: P. Westerhoff (Chair), J. Posner, J. Holway.

[5] Federal Aviation Agency, FAA company website [online]. http://www.faa.gov/ news/press_releases/news_story.cfm?newsId=5785, download 7/30/2012.
[6] D. Gibbons, L. Gruz, EASA company website [online]. http://www.easa.europa eu/ws_prod/g/doc/Events/fueltanksafety_24062005/easa_fueltanksafety_240620 05_ria_issue_1.pdf, 2005, download 8/22/2012.

[7] R.K. Iler, The Colloid Chemistry of Silica and Silicates, Cornell University Press, Ithaca, New York, USA, 1955.

[8] J. Larminie, A. Dicks, Fuel Cell Systems Explained, John Wiley \& Sons, Ltd., West Sussex, England, 2000

[9] X. Li, Z. Li, Q. Xia, H. Xi, Effects of pore sizes of porous silica gels on desorption activation energy of water vapour, Applied Thermal Engineering 27 (2007) 869-876.

[10] J.E. Penner, D.H. Lister, D.J. Griggs, D.J. Dokken, M. McFarland, Aviation and the global atmosphere, IPCC special report, The Hague, 2000.

[11] J.W. Pratt, L.E. Klebanoff, K. Monoz-Ramos, A.A. Akhil, D.B. Curgus, B.L. Schenkmann, Proton exchange membrane fuel cells for electrical power generation on-board commercial airplanes, Sandia National Laboratories, Albuquerque, New Mexico, USA, 2011.

[12] Proflute, Proflute company website [online]. http://www.proflute.se/upload/PDF/ ProFlute_DSR.pdf, 2001, download 8/8/2012.

[13] K. Rajashekara, J. Grieve, D. Dagget, Hybrid fuel cell power in aircraft, IEEE Industrial Applications Magazine (July/August 2008) 54-60.

[14] G. Renouard-Vallet, M. Saballus, G. Schmithals, J. Schirmer, J. Kallo, K.A Friedrich, Improving the environmental impact of civil aircraft by fuel cell technology: concepts and technology progress, Energy \& Environmental Science (March 2010) 1458-1468.

[15] G. Renouard-Vallet, M. Saballus, P. Schumann, J. Kallo, K.A. Friedrich, H. MüllerSteinhagen, Fuel cells for civil aircraft application: On-board production of power, water and inert gas, Chemical Engineering Research and Design 90 (2012) 3-10.

[16] C.R. Ruvio, J.J. Costa, A.R. Figueiredo, On the behavior of hygroscopic wheels, part II - Rotor performance, International Journal of Heat and Mass Transfer 50 (2007) 4823-4832.

[17] J. Sun, R.W. Besant, Heat and mass transfer during silica gel-moisture interactions, International Journal of Heat and Mass Transfer 48 (2005) 49534962 . 